\title{
Kampen mot hiv - to scenarioer
}

Da Leger Uten Grenser startet med antiretroviral terapi (ART) av hivinfiserte i Thailand, Kamerun og Sør-Afrika i 2000, møtte vi stor skepsis. Den dreide seg blant annet om frykt for problemer med etterlevelse og fare for resistensutvikling. Vi og andre erfarte imidlertid at behandlingsresultatene var sammenliknbare med resultater fra vestlige land, både når det gjaldt overlevelse og etterlevelse av behandling (1). Senere studier har vist at velbehandlede afrikanske hivpasienter kan oppnå samme forventede levetid som hivnegative (2). Mer enn fem millioner mennesker er i dag friske takket være hivbehandling.

Problemstillingen er ikke lenger hvorvidt behandlingen virker, men hvor ambisiøse vi skal være i den videre kampen mot hiv. I forbindelse med et FN-toppmøte i New York i juni 2011 forpliktet verdens ledere seg til å behandle totalt 15 millioner mennesker innen 2015. Om dette målet blir nådd, vil spredningen av viruset kunne bremses opp så pass effektivt at vi kan se begynnelsen på slutten av hivepidemien.

Et konsept som har fått mye oppmerksomhet det siste året er «behandling som forebygging». Hivmedisiner reduserer smitterisikoen betraktelig ved å fjerne virus fra blodbanen, og det har lenge vært kjent at antiretroviral terapi under svangerskap, fødsel og amming er svært effektivt for å forebygge smitte fra mor til barn. De siste par årene har en rekke epidemiologiske studier vist en klar sammenheng mellom tilgang til behandling og reduksjon av hivsmitte på befolkningsnivå (3). En randomisert studie av par hvor en part er hivpositiv og den andre hivnegativ, viste dessuten at tidlig hivbehandling (CD4-tall 350-550 celler/ $\mu$ l ved behandlingsstart) reduserte relativ risiko for seksuell smitte med hele $96 \%$ (4). Matematiske modeller tyder nå på at hivepidemien vil kunne endres fra en endemisk situasjon til eliminasjonsfase dersom tilstrekkelig mange får behandling over lang nok tid (5).Visjonen til FN-organet UNAIDS er på sikt å eliminere nysmitte, og delmålet er å halvere nysmitte og aidsrelatert dødelighet innen 2015 ved å satse på primærforebygging og behandling av 15 millioner mennesker (6).

Scenario 1 krever en dedikert, kraftfull og samordnet satsing, men finanskrisen truer dessverre med å sette en effektiv stopper for dette. Flere viktige givere som Verdensbanken, UNITAID/Clinton Health Access Initiative, EU og amerikanske PEPFAR har kuttet øremerkede midler til hivbehandling (7), og det Globale fondet måtte nylig utsette planlagte utbetalinger grunnet finansieringsproblemer. Flere land, blant andre Swaziland og Malawi er nå i ferd med å gå tomme for hivmedisiner, og tusenvis av pasienter risikerer å måtte avbryte igangsatt behandling.

Behandlingsavbrudd øker både sykelighet og dødelighet betraktelig (8) og er i samtlige publiserte studier assosiert med økning i virusmengde og risiko for hivsmitte (9). Ulik halveringstid av medikamentene gir dessuten mulighet for monoterapi i nærvær av økende viremi, og dermed risiko for resistensutvikling. Samtlige studier viser en sammenheng mellom uplanlagte behandlingsavbrudd og resistensutvikling (9). I en studie fra Uganda fant man at $13 \%$ av pasienter med behandlingsavbrudd $>48$ timer utviklet resistens (10). Samtlige utviklet resistens mot nevirapin, som har lang halveringstid, og som er det mest brukte førstelinjemedikamentet i utviklingsland (10). Dette kan ødelegge for fremtidige behandlingsmuligheter, og utgjør på sikt en trussel for oss alle. Det er derfor avgjørende å handle mens vi fortsatt har muligheten.
Finansiering av hivbehandling må ses på som en langtidsinvestering, og helseøkonomiske analyser viser at det er sveert kostnadseffektivt å starte tidlig behandling, i tråd med nye retningslinjer fra Verdens helseorganisasjon (CD4-tall $\leq 350$ celler/ $\mu$ l ved behandlingsstart) (11).

Målet på sikt må være at det enkelte land, i takt med økende økonomisk vekst, færre nysmittede og færre syke, overtar behandlingsansvaret. Frem mot 2015 er det imidlertid både Vestens moralske ansvar og egen interesse å bidra med økonomisk starthjelp.

I en situasjon hvor verdensøkonomien blir stadig mer usikker, er det avgjørende at Norge påtar seg en enda mer aktiv rolle, både ved å øke finansieringen av hivbekjempelse frem mot 2015, og ved å legge vekt på behandling som forebygging i samtlige programmer som mottar støtte. Millioner av menneskeliv står på spill. Norge har en unik mulighet til å spille en avgjørende rolle i en kamp vi kan vinne.

\section{Marius Trøseid}

marius.troseid@medisin.uio.no

Infeksjonsmedisinsk avdeling

Oslo universitetssykehus, Ullevål

Marius Trøseid (f. 1972) er dr.med. og spesialist i indremedisin, har jobbet i felt for Leger Uten Grenser og er for tiden ansatt som postdoktor og hivforsker ved Infeksjonsmedisinsk avdeling, Oslo universitetssykehus, Ullevål.

Ingen oppgitte interessekonflikter.

\section{Litteratur}

1. Ivers LC, Kendrick D, Doucette K. Efficacy of antiretroviral therapy programs in resource-poor settings: a meta-analysis of the published literature. Clin Infect Dis 2005; 41: 217-24.

2. Brinkhof MW, Boulle A, Weigel R et al. Mortality of HIV-infected patients starting antiretroviral therapy in sub-Saharan Africa: comparison with HIV-unrelated mortality. PLoS Med 2009: 6 : e1000066.

3. Montaner JS, Lima VD, Barrios R et al. Association of highly active antiretroviral therapy coverage, population viral load, and yearly new HIV diagnoses in British Columbia, Canada: a population-based study. Lancet 2010; 376: 532-39.

4. Cohen MS, Chen YQ, McCauley M et al. Prevention of HIV-1 infection with early antiretroviral therapy. N Engl J Med 2011; 365: 493-505.

5. Granich RM, Gilks CF, Dye C et al. Universal voluntary HIV testing with immediate antiretroviral therapy as a strategy for elimination of HIV transmission: a mathematical model. Lancet 2009; 373: 48-57.

6. UNAIDS. www.unaids.org/en/resources/presscentre/ pressreleaseandstatementarchive/2011/march/20110331prsgreport/ (14.10.2011)

7. Trøseid M, Johannessen A. Kampen mot hiv kan vinnes, men pengene mangler! Tidsskr Nor Legeforen 2010; 130: 1599-1600.

8. El-Sadr WM, Lundgren JD, Neaton JD et al. CD4+ count-guided interruption of antiretroviral treatment. N Engl J Med 2006; 355: 2283-96.

9. Kranzer K, Ford N. Unstructured treatment interruption of antiretroviral therapy in clinical practice: a systematic review. Trop Med Int Health 2011; e-publisert 1.7. 2011.

10. Oyugi JH, Byakika-Tusiime J, Ragland K et al. Treatment interruptions predict resistance in HIV-positive individuals purchasing fixed-dose combination antiretriviral therapy in Kampala, Uganda. AIDS 2007; 21: 965-71.

11. Walensky RP, Wood R, Ciaranello AL et al. Scaling up the 2010 World Health Organization HIV Treatment Guidelines in resource-limited settings: a modelbased analysis. PLoS Med 2010; 7: e1000382. 